УДК 624.072.31:075.23

\title{
АНАЛІЗ ТА КОНТРОЛЬ БЕЗВІДМОВНОЇ РОБОТИ КОНТАКТНОЇ МЕРЕЖІ
}

О.В. Калюжна, В.М. Шевченко, канд. техн. наук Н.В. Бєлікова

\section{АНАЛИЗ И КОНТРОЛЬ БЕЗОТКАЗНОЙ РАБОТЫ КОНТАКТНОЙ СЕТИ}

\author{
Е.В. Калюжная, В.Н. Шевченко, канд. техн. наук Н.В. Беликова
}

\section{ANALYSIS OF WORK AND CONTROL OF FAULTLESS WORK OF CONTACT NETWORK}

\section{E.V. Kalyuzhnaya, V.N. Shevchenko, cand. of techn. sciences N.V. Belikova}

Безпека руху й експлуатаційна надійність тягового електропостачання визначаються в основному існуючим станом контактної мережі, з технічних і економічних причин споруджуваної без резервування.

Безвідмовна робота контактної мережі забезпечується надійною роботою усіх ї̈ складових. Для забезпечення безпеки $i$ безперебійності руху поӥдів необхідно виконувати постійний аналіз $i$ контроль всіх елементів контактної мережі.

Зроблено аналіз статистичної інформації з надійності роботи контактної мережі по Південній залізниці.

Ключові слова: контактна мережа (КМ), безвідмовна робота, надійність, аналіз, статистична інформація.

Безопасность движения и эксплуатаџионная надежность тягового электроснабжения определяются в основном состоянием контактной сети, по техническим и экономическим причинам сооружаемой без резервирования. 
Безотказная работа контактной сети обеспечивается надежной работой всех ее составляющих. Для обеспечения безопасности и бесперебойности движения поездов необходимо выполнять постоянный анализ и контроль всех элементов контактной сети.

Сделан анализ статистической информачии по надежности работы контактной сети по Южной железной дороге.

Ключевые слова: контактная сеть (КС), безотказная работа, надежность, анализ, статистическая информация.

In conditions, when rail transport is faced with the necessity of finding an effective technology tools, providing the greatest economy of material resources in the delivery process. By keeping traffic volumes, accompanied by the increase in speed, weight train, especially important due to the significant cost becomes the problem of maintenance in operational condition of all elements of the contact network. Implementation of measures to improve the reliability of their work possible through the creation of highly effective diagnostic tools that reduce the cost of providing the required level of reliability.

Traffic safety and operational reliability of the traction power supply is determined mainly by the existing condition of the contact network, for technical and economic reasons under construction without reservation.

Trouble-free operation of the contact network ensures reliable operation of all its components. To ensure the safe and uninterrupted movement of trains is necessary to perform continuous analysis and control of all elements of the contact network.

Keywords: contact network (COP), uptime, reliability, analysis, statistical information.

Вступ. На цей час залізничний транспорт поставлений перед необхідністю пошуку ефективних технологічних засобів, які забезпечують найбільшу економію матеріальних ресурсів у перевізному процесі.

Світова мережа електрифікованих залізничних ліній складає 240,2 тис. км. Загальна протяжність залізниць України складає в даний час близько 30,3 тис. км. Протяжність електрифікованих ділянок залізниць складає $45 \%$ від загальної протяжності, тобто більше 9878 км.

Оптимальним для країн 3 розвиненою залізничною інфраструктурою є електрифікація 50-60 \% загальної довжини залізничних мереж країни 3 виконанням ними 90-95 \% загального обсягу перевезень.

На сьогодні за абсолютною довжиною електрифікованих залізниць Україна посідає 10-те місце серед країн світу і 6-те серед країн Європи.

Згідно 3 "Програмою електрифікації залізниць на 2011-2016 роки", затвердженою в 2011 році, загальна довжина ліній, що електрифікуються, складе близько 14000 км.

В умовах збереження обсягів перевезень, що супроводжується збільшенням швидкостей руху, маси поїзда, особливо актуальної внаслідок істотних витрат, виникає проблема підтримки в працездатному стані всіх елементів контактної мережі. Реалізація заходів 3 підвищення надійності їх роботи можлива за рахунок створення високоефективних засобів діагностування, що дають змогу знизити витрати на забезпечення необхідного рівня надійності.

Постановка проблеми. Безпека руху й експлуатаційна надійність тягового електропостачання визначаються в основному існуючим станом контактної мережі, 3 технічних і економічних причин споруджуваної без резервування.

Безвідмовна робота контактної мережі забезпечується надійною роботою всіх іiі складових. Для забезпечення безпеки i безперебійності руху поїздів необхідно виконувати постійний аналіз і контроль всіх елементів контактної мережі.

Мета. Аналіз статистичної інформації 3 надійності роботи контактної мережі по Південній залізниці.

Основний матеріал. Частка відмов технічних засобів через старіння, корозію і знос залишається високою, особливо на ділянках першого етапу електрифікації. Найбільша кількість відмов відбувається через недоліки в експлуатаційній роботі і технічні параметри елементів системи, проте значна частина збоїв пов'язана із зовнішніми чинниками - умовами експлуатації і довкіллям.

На контактну мережу впливає безліч чинників, що призводять до відмов і навіть 
аварій. Вироблення ресурсу деталей i конструкцій контактної мережі пов'язане 3 накопиченням необоротних пошкоджень. Ці пошкодження бувають як механічного, так i фізико-хімічного характеру. До першого належать пошкодження несучих i підтримувальних металевих конструкцій, зношування контактних дротів, накопичення пластичних деформацій у затискачах, розтріскування фарфору ізоляторів. До другого характеру пошкоджень належать корозія арматури залізобетонних опор контактної мережі й інших металевих деталей, хімічні перетворення бетону під дією агресивних середовищ, окислення складових дротів та тросів при нагріванні. Багато видів пошкоджень носять змішаний характер, наприклад, знос контактних дротів включає явища механічного (тертя), фізичного (електрокорозія) і хімічного (утворення вторинних структур поверхні) походження.

У системі тягових електростанцій контактна мережа (КМ) $є$ єдиним нерезервованим елементом, тому до неї ставляться найбільш високі вимоги щодо надійності функціонування. КМ $є$ складною технічною системою, що виконує передачу енергії i бере участь у струмозніманні. Відсутність резерву і схильність до інтенсивних навантажень викликають розвиток процесів деградації і відмови КМ. Особливості конструкції й умов роботи КМ зумовлюють значну частку раптових відмов, викликаних різними діями. Це можуть бути аварійні відхилення дротів при вітрі, недопустимі навантаження ожеледі, несправні струмоприймачі, вандалізм і т. д. Одночасно існує велика група поступових відмов, викликаних деградаційними процесами.

Діагностування контактної мережі процес визначення стану пристроїв контактної мережі з метою підвищення іiї безвідмовності і зниження витрат праці й коштів на ії технічне обслуговування та ремонти. Діагностування контактної мережі $\epsilon$ частиною технологічного процесу технічного обслуговування контактної мережі, що дає змогу визначити стан об'єкта 3 необхідною точністю. Результатом $є$ діагноз технічного стану об'єкта 3 вказівкою дефекту, його місця, виду і причини. Система технічного діагностування контактної мережі є сукупністю засобів і об'єктів діагностування й виконавців, що дає змогу реалізувати поставлене перед нею завдання за встановленими правилами i програмами.

Засоби технічного діагностування контактної мережі утворюють комплекс спеціалізованих пристроїв і приладів, які розділяються на зовнішні і вбудовані. Зовнішніми засобами $\epsilon$, наприклад, вагонлабораторія контактної мережі і різного виду ручні прилади для дистанційного контролю ізоляції, нагрівання струмопровідних елементів, опор. Вбудовані пристрої використовують для контролю окремих параметрів (наприклад, при тепловому захисті дротів).

Інформація 3 вбудованих пристроїв передається по оптичних, оптоелектронних, механічних (через ізоляційний елемент) i радіоканалах, а також через ізолюючі трансформатори. Обробка й аналіз вихідних сигналів 3 датчиків, встановлених на елементах контактної мережі, виконуються за програмами, розробленими для кожного з них, а також за програмою, що об'єднує ці сигнали.

Обробка інформації здійснюється як бортовими (вагонів-лабораторій), так і стаціонарними ЕОМ. Обробка сигналів про ознаки (параметри) виконується бортовими EOM у реальному масштабі часу для оперативної видачі діагнозу персоналу районів контактної мережі. Інші сигнали й інформація, що не потребують реєстрації в реальному масштабі часу, обробляються стаціонарними ЕОМ для видачі діагнозу персоналу, зайнятому плануванням ремонтів i підвищенням надійності контактної мережі.

Висновки. При здійсненні контролю стану об'єктів переносними приладами i пристроями, що працюють дистанційно або у контакті 3 контрольованими об'єктами, для систематизації й аналізу відомостей про роботу цих пристроїв використовують паспортні карти пристроїв і картки відмов. У паспортній карті в хронологічній послідовності відбиваються всі події, пов'язані із зміною стану і роботою цього пристрою, міститься інформація про всі ремонти i випробування, повні i часткові відмови.

В узагальненому вигляді інформація групується по чотирьох розділах: основні характеристики; контрольовані параметри i регламентовані роботи; характеристика відмов; витрати, збиток, напрацювання. Відхилення одного або декількох параметрів за межі, встановлені нормативно-технічною 
документацією, при якому зберігається працездатність пристрою і він може тимчасово використовуватися за призначенням, класифікують як часткову відмову; відхилення параметрів від норм, при якому використання пристрою за призначенням неможливе, - як повну.

Для обробки інформації про відмови використовують також спеціалізовані облікові картки відмов. Повна відмова пристрою i викликана ним відмова об'єкта фіксуються одночасно в одній картці. У разі великих пошкоджень, коли виділення окремих пристроїв неможливе, складається одна картка на об'єкт у цілому. Статистична обробка інформації зіставлення іiі результатів (при одночасному обліку відмов елементів контактної мережі) за визначений проміжок часу дає змогу 3 високою ймовірністю оцінювати можливу тенденцію до змін показників мережі у цілому та іiі окремих елементів, прогнозувати час досягнення показниками граничних нормованих значень.

\section{Сиисок використаних джерел}

1. Золотов, М.С. Прочность и деформативность железобетонных элементов с трещинами, затонированными акриловым клеем [Текст] / М.С. Золотов, В.А. Мельман // Науковий вісник будівництва. - Харків: ХДТУБА, 1999. - Вип. 8. - С. 250 - 252.

2. Коррозия и защита сооружений на электрифицированных железных дорогах [Текст]/ А.В. Котельников, В.И. Иванова, Э.П. Селедцов, А.В. Наумов. - М.: Транспорт, 1974. - 152 с.

3. Даренський, О.М. Вплив стану колії на безпеку руху промислових залізниць [Текст] / О.М. Даренський // Зб. наук. праць. - Донецьк: ДонІІЗТ, 2012. - № 29. - С.131-136.

4. Старосельский, А.А. Электрокоррозия железобетона. [Текст] / А.А. Старосельский. - К.: Будівельник, 1978. - 169 с.

5. Трещины в железобетоне и коррозия арматуры [Текст] / В.М. Москвин, С.Н. Алексеев, Г.П. Вербицкий, В.И. Новгородский. - М.: Стройиздат, 1971. - 144 с.

6. Чихладзе, Э.Д. Оценка несущей способности сталебетонных колонн различного поперечного сечения при действии нагрузки и температуры, включающей пожар [Текст] / Э.Д. Чихладзе, М.А. Веревичева // Строительство, материаловедение, машиностроение. - № 47. Днепропетровск: ПГАСА, 2008. - С. 684-690.

7. Шагин, А.Л. Об оценке работы бетона в условиях сложного напряженного состояния [Текст] / А.Л. Шагин // Реализация региональной комплексной научно-технической целевой программы “Бетон”: тез. докл. обл. конф. - Харьков, 1983. - С. 28 - 30.

8. Жинкина, Г.Н. Железнодорожное строительство. Организация, планирование и управление [Текст]: учеб. для вузов ж-д. транспорт.; под ред. Г.Н. Жинкина. - 4-е изд., перераб. и доп. - М.: Транспорт, 1985. - 372 с.

9. Грушко, И.М. Основы научных исследований. [Текст] / И.М. Грушко. - Харьков: Высш. шк., 1983. $-223 \mathrm{c}$.

10. ДНАОП 5.1.11-1.48-00. Правила безпеки для працівників залізничного транспорту на електрифікованих лініях [Текст]. - К., 2000.

Рецензент д-р техн. наук, професор А.А. Плугін

Калюжна Олена Вячеславівна, технік КМС-131 Південної залізниці. Тел.:+380958010212.

Шевченко Валентин Миколайович, магістр, слухач Української державної академії залізничного транспорту.

Тел.: +380664615507.

Бєлікова Наталія Віталіївна, канд. техн. наук, доцент кафедри колії та колійного господарства Української державної академії залізничного транспорту. Тел.: +380577301067

Kalyuzhnaya Elena Vyacheslavovna, techniques CCM-131 southern railway. Phone:+380958010212.

Shevchenko Valentin Nikolaevich, master, listener the Ukrainian state Academy of railway transport. Phone: +380664615507 .

Belikova Natalia V., cand. of techn. sciences, Professor Department of road and railway equipment of the Ukrainian state Academy of railway transport. Phone: +380577301067 . 